ARTICLE

\title{
The Third Modulation: Foucault, Security and Population
}

\author{
RICHARD TOGMAN \\ Lakehead University, Canada
}

\begin{abstract}
Evolving as Foucault's third modulation of power, security power marks a radical departure from previous eras of sovereign and disciplinary power. Dramatically decentering the individual, altering the means by which government acts and shifting from a static to a dynamic conception of temporal activity, an understanding of Foucauldian security power provides a number of critical insights into modern governance. This paper seeks to explain and analyze Foucault's conceptualization of security power as the new language of governance and apply it in relation to the pervasive phenomena of government attempts to control fertility. Using the cases of inter-war France and post-colonial India, the theorization of security power will be grounded in the realities of natalist policy demonstrating the universality of the exercise of security power and its applicability to numerous contexts and settings. The concretization of theory in case study not only illuminates the workings of a new model of power but highlights the difficulty of resisting this novel type of government control. Understanding power to understand modes of resistance is central to the Foucauldian method, and drawing from Foucault's newly translated lectures, this paper will bring to light a fascinating mode of analysis which helps illuminate the evolving nature of power and control in the modern era.
\end{abstract}

Keywords: security; discipline; foucault; population politics; demography; population control

The language of power has changed over the last thirty years as the work of Michel Foucault has introduced a whole new vocabulary to the understanding of governance. Exploring the basic operating mechanisms of the structures of power which works on and through individuals, Foucault articulates three fundamental ways in which the state has sought to maintain control of, act upon and maximize its capabilities through those under its charge: sovereign, discipline and security power. While the history of sovereign power has been well established and a plethora of literature has emerged articulating the various 
disciplinary mechanisms which have evolved over the recent past, the field of security power has been relatively understudied and is fruitful ground for exploration. This article seeks to explore the concept of security power as articulated by Foucault in his work Security, Territory, Population ${ }^{1}$ and its application to the study of population control in the cases of inter-war France and post-colonial India.

Just as disciplinary power has wide ranging applications in society and has been studied in contexts ranging from the prison to education and health care, security power is a similarly widespread and pervasive social phenomenon. Theoretical exposition of this subject is critical, as is the concretization of theory in historical practice as the practices of security power have been routinely ignored in the literature. Thus, this article will examine the theory of security power in the first half of the article, as discussed by Foucault, which will be followed by case studies of inter-war France and modern India in relation to their respective attempts to control fertility and population growth. These cases are important not just for the concretization of theory in practice but also to understand the nature of population politics itself. State management of fertility has become a pervasive feature of the $20^{\text {th }}$ and $21^{\text {st }}$ centuries with over $85 \%$ of governments worldwide utilizing a security approach to controlling the reproductive powers of their citizens. ${ }^{2}$ Foucauldian security is the new unspoken language of state power and thus understanding security power is critical to understanding the modern application of state power as such.

Moreover, this new form of power makes resistance to the state increasingly difficult. Foucauldian security does not merely shift the object of governance but alters the very modes of action, which makes targeted resistance an elusive goal. Thus a major goal of this work will not be to criticize or problematize security as such but rather to illuminate its operation and uncover ground where action may be taken to offer better resistance when necessary. Grounding itself in the realities of state control, this article seeks to lay the theoretical foundations for directed action and uncover the complexities which explain why resistance has so often failed.

Efforts to control population growth have been a pervasive phenomenon of the $20^{\text {th }}$ and $21^{\text {st }}$ centuries with most governments of Europe, Asia and Africa subject to some form of attempted manipulation of the procreative powers of the population. While this phenomenon has been subject to extensive study by historians, demographers, sociologists and anthropologists ${ }^{3}$, this powerful modern movement has been little studied from a theoretical position related to the exercise of security power. ${ }^{4}$ Little research has been done

\footnotetext{
${ }^{1}$ Michel Foucault, Security, Territory, Population: Lectures at the College de France 1977-78 [2004] (2009)

${ }^{2}$ United Nations Department of Economic and Social Affairs Population Division, World Population Policies 2013 Report (2013).

${ }^{3}$ Matthew Connelly, "Seeing Beyond the State: The Population Control Movement and the Problem of Sovereignty" Past and Present 193 (2006): 197-233, Paul Demeny, "Population Policy: A Concise Summary" Population Council, Policy Research Division, Working Paper No. 173 (2003), Dennis Hodgson, "Demography: Twentieth Century History" International Encyclopedia of the Social and Behavioural Sciences (2001), Simon Szreter, "The Idea of Demographic Transition and the Study of Fertility Change: A Critical Intellectual History" Population and Development Review $19: 4$ (1993): 659-701.

${ }^{4}$ With the possible exception of Greenhalgh. Susan Greenhalgh, "The Chinese Biopolitical: Facing the Twenty-First Century" New Genetics and Society 28:3 (2009): 205-222.
} 
which would explain why, as of 2013, 171 out of 194 states are actively trying to control the reproductive powers of their citizens. ${ }^{5}$ The cases of inter-war France and post-colonial India will be examined to help elucidate the modes of governance related to security power as these cases represent a divergent sampling of states which have been exemplars of security power in relation to their attempts to control the population. Their diverse settings, time and place serve as an excellent grounding point to demonstrate the universality of the exercise of security power and will be used primarily to demonstrate the mechanisms of security power in action to concretize the theoretical discussion of the first half of the article. Moreover, a comparison of the cases will help demonstrate not only the workings of security power but also provide a rationale for why policies may fail as well as why organized resistance is often frustrated.

Thus, much will not be examined as each case has a unique history and it is not the purpose of this paper to explore in depth the ways in which fertility has been controlled in any particular case. Rather the cases are meant to illustrate particular commonalities in modes of governance across widely divergent spatial and temporal cases and to highlight the fundamental operations of security power's modus operandi. Without an appreciation of security power, one is liable to underappreciate the essence of much state activity which pervades the international political landscape.

\section{Shifting the Object of Governance}

Security power is fundamentally different from Foucault's more popularized concepts of sovereign and disciplinary power. While evolving last and representing the most recent incarnation of governmentality, it diverges from earlier forms of power in its very conceptualization of the object of governance, the means to govern the object and the devices used to maximize its objective. Under sovereign and disciplinary forms of power, the individual is the object of governance. Power seeks to act on the bodies of the governed in an immediate and tangible manner as the workings of the state are inscribed on the physicality of its subjects. The object of governance, the individual, is bent to the will of the state, often through sheer force. In the case of sovereign power, this may take the form of public torture or execution as obedience to the will of the regime is enforced through the ability of the state to kill or let live. ${ }^{6}$ After obedience to the sovereign is assured, sovereign power places relatively few demands on the everyday lives of its subjects. ${ }^{7}$

Disciplinary power represents an evolution of power as while the object is still the individual, the scope of obedience and control demanded by the state is amplified exponentially. The perfectibility of the object is, at heart, the guiding truth of disciplinary power. The state seeks to govern the totality of elements which shape the behaviour of the individual as both the outer life of the individual, in terms of the regimentation and surveillance of time and space, as well as the inner life of the object, in its concepts of truth, morality, duty and aspirations, fall under the legitimized realm of governance. The state

\footnotetext{
${ }^{5}$ United Nations, World Population Policies 2013

${ }^{6}$ Michel Foucault, Discipline and Punish: The Birth of the Prison (1995), 8.

${ }^{7}$ Michel Foucault, Discipline and Punish, 34.
} 
seeks to discipline the object such that the whole of its existence is captured and harnessed to serve ends that maximize its social utility and transform it into a docile and capable individual. Control over the individual allows the state to grow in strength and the power of the state can be assessed in terms of the sum of the successful disciplining of numerous individuals. $^{8}$

Security power marks a significant break as it reorients the object of governance away from the individual and towards the collective. The 'population' becomes the object of governance and individuals per se are merely a means to reach that end. The object is not a tangible reality and no physical body is being worked upon with direct intent but rather the physicality of reality is a tool to arrive at an intangible as security power "works at the level of the imaginary reality". 9 The concept of the population is more important than any real individual and furthermore an individual may be ultimately expendable to achieve an idealized abstraction. ${ }^{10}$ This is a critical evolutionary leap in the conceptualization of power and purpose as the state effectively detaches itself from the lives of any particular individuals or groups of people and works solely at the level of the concept of the people as told through an aggregated and anonymized construction. Statistical tables, average indicators and rates of occurrence create the abstracted reality of a people and the individual story is told through the creation of an entirely fictional individual - the average person - as "sovereignty is exercised within the borders of a territory, discipline is exercised on the bodies of individuals and security is exercised over a whole population". ${ }^{11}$

Whereas previously the state mandated the disciplining of the individual such that each and every person would comply with government directives under security power, the state detaches itself from the micro-terrain and concerns itself with the macro-features of society. Instead of focus being on absolute compliance, the focus is on generating norms, acceptable ranges and optimal averages. Perfection is abandoned in favour of optimization as "one works in probabilities" because security power is "a matter of maximizing the positive elements and minimizing the risky or inconvenient while knowing that they will never be completely suppressed". ${ }^{12}$ Foucault describes "statistics and 'normality' (being) linked together and to security"13 as while "discipline allows nothing to escape... (the) smallest things must not be abandoned to themselves", ${ }^{14}$ the overarching question of security is "how to keep a type of (behaviour) within socially and economically acceptable limits and around an average that will be considered as optimal for a given social functioning". ${ }^{15}$ Thus the exercise of security power is a never ending process and one in

\footnotetext{
${ }^{8}$ Discipline and Punish, 81.

${ }_{9}^{9}$ Michel Foucault, Security, Territory, Population, 47.

${ }^{10}$ Michel Foucault, Society Must be Defended: Lectures at the College de France 1975-76 [1992] (1997), 242.

11 Security, Territory, Population, 11.

12 Ibid., 19.

13 Ibid., 62.

14 Ibid., 45.

15 Ibid., 4.
} 
which the concept of flow and circular motion respecting certain rhythms of society operates. While disciplinary power seeks rigid control and works on assumptions of perfectibility and a utopian finality, security power stands on the shoulders of disciplinary power to see the greater whole and direct larger outcomes with no definitive end. Exercising power at the macro-social level acknowledges the potential insignificance of the individual as an individual, and while policy ultimately works through the particular, it is the movement of the general that is most relevant.

Foucault articulates the example of the thief in chapter one of Security, Territory, Population to concretize the meaning of the shifts from sovereign to discipline and on to security forms of power. In this example, the government edict 'thou shalt not steal' is accompanied by certain punishments if one breaks the law. Under sovereign power, a thief may be publicly executed in the "spectacular, definitive moment of the hanging" such that the individual who transgressed and hence challenged the authority of the state is dealt with and the power of the state over life/death is reinforced for all observers to see and bear witness. Under disciplinary power, while the state retains the authority to kill, control over the moment of death is not the object. Rather, a new institution is created in the form of the justice system where the police, prison and parole administrations in combination with social workers and psychologists form a nexus of governance. Detailed records are kept of a multitude of individuals who are deemed at high risk of offense, surveillance systems are established to monitor high crime areas to deter and capture perpetrators and once an individual violator is caught up in the system, a rigidly thorough constellation of techniques are applied. To discipline the body of the thief, control is exercised over time and space in the prison system while continuous efforts are made to rehabilitate and reform the soul of the individual such that he/she will be saved from a life of crime and successfully reintegrated into respectable society to become a productive, tax paying citizen. ${ }^{16}$ The focus is on the criminal as the object is the individual.

Security power is the "third modulation" which is largely based on the same matrix of law, punishment, surveillance and correction as disciplinary power; however, the focus fundamentally shifts as the individual is no longer the object of concern and the perfectibility of the individual and society no longer the objective. Instead the apparatus of governance is ruled by a new set of questions and desires:

what is the average rate of criminality for this type? How can we predict statistically the number of thefts at a given moment in a given society... are there times, regions, and penal systems that will increase or reduce this average rate?...how much does criminality cost society... what is the cost of repressing these thefts? Does severe and strict repression cost more than one that is more permissive... what is the comparative cost of theft and of its repression and what is more worthwhile: to tolerate a bit more theft or to tolerate a bit more repression? ${ }^{17}$

16 Ibid.

17 Ibid. 
Ultimately the very purpose of the entire system shifts. Instead of trying to prevent and punish crime and to discipline individuals into becoming good, productive and loyal citizens, the focus of government revolves around the question of keeping a type of criminality, theft for instance, within socially acceptable limits such that governance of the act of theft will be cost-effective for the population as a whole. The state gives up on the goal of completely suppressing theft and works in probabilities at the level of the collective. The individual transgressor is unimportant as theft is acknowledged as a type of social regularity which need not be stamped out but adjusted to ensure optimal social functioning.

This shift in the object of governance has profound consequences as the entire locus of government control moves under security power. This is not to say that sovereign or disciplinary power disappear, rather they are incorporated into yet decentered from the overall mechanisms of power operating within the state. All three modes exist simultaneously as it is their relative dominance in the system that changes. ${ }^{18}$ Security power allows for a whole new range of discourses to operate and truths to be enacted on the population, as the population itself is a rather blank slate upon which truths can operate with greater ease than on the individual. As well, resistance, while still possible, becomes more convoluted as those in power only seek legibility at the level of the aggregate and the abstractions they create have no voice. While under sovereign and disciplinary power individuals may resist and their voices may be heard by those seeking to act on them as objects (even though their cries may fall on deaf ears), under security power the voice of the individual may not even be registered as the fundamental irrelevance of any particular individual and the total obsession with the macro by the state renders protest, opposition and resistance potentially more challenging. This may be so to the degree that the state may not comprehend whether policy is a success or failure as the object they seek to govern has neither voice nor agency but the voice they ascribe to it. This will become evident when examining the case of population control as the quest to make the population legible to policymakers often makes the individual illegible as a corollary.

\section{The Means to Govern the Object}

Security power differs fundamentally in the means by which it seeks to shape the norms of society. Sovereign power neglects, or rather ignores, the majority of behaviours which occur under its rule, largely restricting itself to the power to let live or cause death, and disciplinary power attempts to make legible the individual lives of those under its charge by recording and surveying the details of their existence to better perfect their operation. In contrast, security power seeks to optimize the population by "having a hold on things that seem far removed from population but which, through calculation, analysis and reflection, one knows one can really have an effect on it". ${ }^{19}$ The locus shifts from knowledge of the individual itself to knowledge of the environmental factors affecting the population.

\footnotetext{
18 Ibid., 8.

19 Ibid., 72.
} 
It is the view of "man as human species" 20 that defines security power as the population and the factors influencing its behaviour are seen more as a set of variables to be manipulated at the macro scale than as discrete objects to be disciplined at the micro scale. Most often, agency itself is largely absent in the state's perception of individuals. With the realization that individuals cannot be accurately predicted but movements at the level of the population can be, governments have taken to viewing the population as a somewhat inert object which will be responsive to changes generated from the top down so as to engineer optimal outcomes at the aggregate. ${ }^{21}$

Under disciplinary power the state maintains and targets activities directly at individuals, while under security power there opens up a whole new set of tools whose utility lies in their indirect application. The direct consequences of their application are not the prime motivator but rather the indirect results of their application become a dominant consideration. For example, in 1966 the state of Romania banned abortion. This was not due to a conservative or theologically inspired directive relating to the sanctity of life nor was it grounded in any type of moral opposition to abortion in general. Rather, the act of the ban on abortion was intended to increase the fertility rate of the population as a whole. ${ }^{22}$ By outlawing the most common contraceptive practice of the population, the government intended to deny women the tools of family planning so as to lead to an increase in births (those who had fulfilled their demographic duty and had four children were allowed access to abortion). ${ }^{23}$ This increase in births was intended to increase the average number of births a woman would have over her lifetime, leading to increased rates of population growth which, in turn, were understood to contribute to national power. Thus, targeting abortion was intended to lead indirectly to increased national power, which was the true focus of policy. ${ }^{24}$ Many more examples of this type of behaviour will be discussed in the case studies below.

This type of utilization of power is radically different from that under sovereign or disciplinary power. Under both of these older forms of power, the law is crafted with direct intent and the consequences of its enforcement are understood to be the direct results which spring forth as individuals comply or resist directives. For example, an antiabortion stance may be taken by a government as a moral imperative. Utilizing sovereign power the state may simply choose to publicly execute those convicted of having performed abortions as disregard for the law may be seen as representing a challenge to the authority of the government. Alternatively, using disciplinary mechanisms, police powers may be used to shut down abortion clinics, the penal system may apply 'corrective'

\footnotetext{
20 Ibid., 75.

${ }^{21}$ Ibid., 74.

22 Gail Kligman, The Politics of Duplicity (1998), 1.

${ }^{23}$ Gail Kligman, "The Politics of Reproduction in Ceausescu's Romania: A Case Study in Political Culture" East European Politics and Societies 6: 364 (1992): 377.

${ }^{24}$ Thomas Keil and Viviana Andreescu. 1999. "Fertility Policy in Ceausescu's Romania", Journal of Family History 24:4: (1999): 482.
} 
measures to reform medical personnel accused of performing illegal operations and public education campaigns 'educate' individuals concerning their moral duties towards the unborn. All of this may be intended to stop an act deemed anti-social with the indirect consequences of such a policy being unintended, such as the rise of single mothers, an increase in illegal abortions or perhaps merely the increase in use of other forms of family planning such as condoms or abstinence. This discussion is not meant to take a position on the abortion issue but merely to highlight the alternate intent policies may have, because while the act of banning abortion may be the same, it is the intent of policy which is fundamentally different. Under disciplinary power the goal is to change individual behaviour writ large and the means used are direct, while under security power the objective is to alter the rate of occurrence in a population by targeting a factor which is not directly related to the objective but which through analysis one predicts that the scale of the population has a high probability of success in achieving the desired outcome.

The exercise of power in this manner has the potential to provide for more subtle manipulations of the social body but may also make appeals for reform from the citizenry more challenging. The indirect approach to social engineering makes the site of contestation more elusive as the protesting body may be forced to gather support not only for the reform of the direct mechanism but also garner backing to address the indirect aim of the state. For example, in Nigeria in the late 1980s the government undertook efforts to promote contraception and family planning. This was done not out of any great concern on behalf of the state for the cause of family planning per se but was implemented as a tool to indirectly affect the rate of economic growth. The orthodoxy of the era stipulated that high fertility was leading to a poverty trap and only through reducing fertility could the government kick-start economic growth. Thus the distribution of contraception and family planning knowledge was designed as a tool of economic policy. ${ }^{25}$

In northern Nigeria there was a significant backlash against government programs of this nature, often from Islamic communities who opposed government attempts to restrict fertility on religious and cultural grounds. However, efforts by local communities to build resistance to these policies became increasingly difficult as simply addressing issues of control over female reproduction, while being the direct policy, was not sufficient to sway the regime. The major aim of government intent was the indirect effect that family planning programs were believed to have on economic growth, and Islamic representatives found their efforts frustrated as the demands of the economy overrode their wishes for autonomy in matters of reproduction. ${ }^{26}$ In effect, those seeking to resist and reform family planning programs would first need to overcome those who have a direct stake in the policy as well as those who have an indirect interest in the program.

In seeking to grow the economy, the Nigerian government used indirect means in pushing family planning programs on northern, rural Nigerians. The government was

${ }^{25}$ Elisha Renne, "Perceptions of Population Policy, Development and Family Planning Programs in Northern Nigeria" Studies in Family Planning. 27:3 (1996): 132.

${ }^{26}$ Renee, "Perceptions of Population Policy, Development and Family Planning Programs in Northern Nigeria". 
not concerned that every single Nigerian woman used contraception but was rather preoccupied with the rate of contraceptive use and the change in the fertility rate. The behaviour of the average Nigerian woman became paramount as through this manipulation of social norms relating to child bearing, the state sought to indirectly grow the economy and strengthen the powers of the regime. Any contestation of this agenda would likely have to contend with multiple sites of power and legitimizing discourses as resistance based on cultural opposition to family planning may address merely one aspect of the program, which in this case is not even the most significant or crucial front. A second front may need to be opened to challenge the narrative which stipulates that lower fertility leads to economic growth or perhaps to resist the very notion that principles of economic growth outweigh cultural values relating to fertility. Due to this kind of indirect attempt to manipulate society to achieve state aims, it is likely more difficult to challenge, resist and potentially force reform of state actions. Thus, under security power, the language of power shifts from the perfection of the individual to the optimization of an average indicator, the means shift from direct to indirect and as a result the path to resistance became more convoluted and challenging.

\section{A New Direction for the Tools of the Trade}

The conceptual devices which security power relies on, such as statistical constructs, aggregations, averages and rates of occurrence, are deeply enmeshed with the systems of power-knowledge, more so than in discipline or sovereign power. The tools and techniques of scientific knowledge generation are tightly intertwined in the mechanism of security power as the state becomes interdependent with a wide range of actors tasked with the gathering, analysis, elaboration and synthesis of information on a macro-scale. ${ }^{27}$ Statisticians, sociologists, demographers, economists and a host of academic and intellectual communities must work with and alongside an extensive state bureaucracy to both 'know' and make 'legible' the population to those in power. ${ }^{28}$ The state becomes involved in sponsoring the active construction of the object of the population through the collection of data in the form of the census, for example. The census requires an enormous effort by the state administrative and bureaucratic organizations to organize a workforce capable of gathering data in addition to a professional class which, once trained in the arts of aggregation, must distill the raw data of individual human lives into the information deemed necessary to make legible the macro behaviours of the people. For example, in the recent Chinese census in 2010, the Chinese government hired an additional six million employees over and above the regularly employed staff of the census and statistical bureau. This represents an organization over three times larger than the Chinese army. ${ }^{29}$ The sheer administrative power of the state harnessed for knowledge gathering is crucial for the optimal operation of security power.

\footnotetext{
${ }^{27}$ Foucault, "Society Must be Defended", 246.

28 James Scott, Seeing Like A State (1999).

${ }^{29}$ Mark MacKinnon, China Undertakes First national Census in 10 Years. The Globe and Mail (2010, 31 Oct).
} 
In addition, a wide variety of non-state actors are active players in the construction of the population as an object of governance as well as in the discursive legitimation of state authority through the construction of narratives validating the operation of security power. For example, in the case of population control in the developing world, countless demographers, economists, military planners, political scientists, biologists, doctors and other members of the academic and intellectual community were critical in legitimizing the state's role in manipulating the procreative powers of the citizenry. A new discourse on the meaning of population growth was created and propagated by the centers of knowledge in both the developing and developed world such that a new duty was adopted by the state - to reduce fertility so as to bring about the modernization and development of the country. ${ }^{30}$ Those entrusted by the population to create knowledge created the narrative of a relationship between fertility and economic growth which became so dominant as to achieve the status of a 'truth'. Population control was deemed vital to development efforts, thus states were not only supported in their efforts to exert a new level of control over the population but those states failing to employ these powers were criticized and labelled as backwards. ${ }^{31}$

Population control's basic truth lay in the realm of security power as the individual was not of concern but rather the fertility rate of the population as a whole became the site of governance. The disciplinary powers of the state were a means to achieve an end that lay beyond the perfection of the individual because the average person, not the individual per se, was the object of concern. Deviations from the optimal individual behaviour could be tolerated conceptually (if not always in practice) as compliance with idealized fertility practice only mattered in as much as a new norm was created, new aggregates achieved and rates of occurrence stayed within acceptable limits, as understood by the intellectual community which informed the state. New states were socialized into this new language of state-ness as fluency in the language of security power became necessary to be considered modern. As will be shown in the cases below, the very essence of population control lay in the conceptual realm of security power as without security power, efforts at lowering fertility bore little direct meaning.

The state had no need for these types of knowledge gathering activities or personnel under sovereign power, and while disciplinary power often utilizes the extensive systems of power-knowledge built up in the twentieth century, security power is utterly dependent on a deep and extensive system of knowledge gathering, analysis and administration. Its very premise is predicated on an apparatus of power-knowledge and the harnessing of massive amounts of data combined with sophisticated instruments of analysis, such as statistical tools, to make real the very constructs the state wishes to manipulate. One can see this very distinctively in the case of population control as over the course of the 1960s and 1970s the post-colonial developing world underwent a process whereby the UN,

\footnotetext{
${ }^{30}$ Hodgson, "Demography: Twentieth Century History", Szreter, "The Idea of Demographic Transition and the Study of Fertility Change: A Critical Intellectual History".

${ }^{31}$ Deborah Barret and Amy Ong Tsui. "Policy as Symbolic Statement: International Response to National Natalist Policies" Social Forces 78:1 (1999): 213-234.
} 
World Bank and western development agencies funded and trained a complimentary network of institutional structures designed to facilitate the rise of a knowledge generating class within the developing world to allow for the mechanisms of power-knowledge to work autonomously in a wide variety of settings. For example, the UN Secretariat was active in establishing the first censuses of many African states with the Population and Statistical Commission being critical to enabling an institutional capacity to record demographic and vital statistics. ${ }^{32}$ The apparatus of knowledge generation through state bureaucratic and administrative power is essential to the mission of population control as without the detailed data gathered by the state, the population remained a concept illsuited to manipulation. The very abstraction of the population lost any foundation in reality and the state lay crippled in the application of its powers as it lacked the means by which to populate its abstractions. Thus many African states had to be educated/socialized by the international community in the steps necessary to make the practice of security power possible in the context of population control. ${ }^{33}$

It is important to note that security power is not merely the act of aggregation or 'massifying' the individual into a collective as it is not the sum of individuals which ultimately matters. Also, security does not seek to gain the totality of information on the totality of individuals to better know and govern every individual. The individual or individuals are not truly the object of concern and instead an entirely new abstraction is effectively created as 'the population', an almost separate reified entity, works under its own logic and is understood to operate under its own principles. In tandem, security power is about governing motion and a 'natural' flow of behaviours. While traditional forms of power effectively govern snapshots in time, looking at the number of crimes committed, children educated or babies born, Foucauldian security governs an active, reified entity. The crime rate, literacy rate and fertility rate are the sites of governance which belong to the object of the population. At any given moment one can ascertain what is occurring in real time through a knowledge of the characteristics of the population. Thus one governs the population in real time through the manipulation of rates and averages as it is the movement of these statistical constructs that inform government. Accordingly, the nature of governance fundamentally changes under security power as its basic comprehension of what is being governed (the population), the means to governing (indirect) and the metrics of governance (rates, averages) are different from previous eras. This is important not just to understand the nature of modern governance but to inform the means and possibilities of resistance to the state. Resistance becomes increasingly complex as those challenging existing structures must contend with a power that, in extremis, does not acknowledge the individual and whose modus operandi makes locating the actual site and intent of action difficult.

\footnotetext{
${ }^{32}$ Stanley Johnson, World Population and the United Nations: Challenge and Response (1987), xxii.

${ }^{33}$ Connelly, "Seeing Beyond the State", 228. World Bank, The McNamara Years at the World Bank (1981), 14. John Caldwell and Pat Caldwell, Limiting Population Growth and the Ford Foundation Contribution (1986), 117.
} 


\section{CASE STUDIES}

\section{France}

While the history of French efforts to control population growth extends beyond the $20^{\text {th }}$ century, the inter-war period marks a relatively unique time where attempts to grow the population through the manipulation of fertility were at their relative height. One can see the mechanisms of security power most clearly here as it saturates the discourse and practice of pro-natalism. To understand the context of French pro-natalist activity, one must understand the pre-existing discourses of power being propagated by the academic and intellectual communities of Europe at the time. In this era, there was a firm 'truth' in operation which stated that a key metric of national power was the size of one's population; not in an absolute sense but rather the rate of population growth signified the enlarged potential for military manpower, increased economic strength, enhanced cultural prestige and an overall virility and vitality of the population.

This economy of truth on the matter of population was intimately bound up in the power-knowledge apparatus as this did not represent a mere concoction of fringe propaganda but was endorsed by the leading politicians, academics, businessmen and cultural leaders of the time. For example, one of the most influential non-government organizations in French society at the time was the 'Alliance Nationale Pour L'acrroissement de la Population Francaise'. Membership of the organization ranged from Emile Zola, a leading cultural figure, to Edouard Michelin, head of the wealthy industrialist family, as it sponsored and produced a wide range of materials designed to influence the French public of its "patriotic duty of procreation" and lobbied parliament to produce pro-natalist legislation. ${ }^{34}$ The promotion of the pro-natalist discourse by organizations such as the Alliance Nationale was extremely successful; in 1911 the pro-natalist block in parliament boasted about 1 in 5 deputies, whereas by 1924 approximately 3 out of every 5 deputies openly allied themselves with the pro-natalist movement. ${ }^{35}$

The drive to higher fertility was fueled by a drive for state power. Neither the government nor civil society organizations such as the Alliance Nationale cared about fertility per se nor did they seek to control fertility as part of a religious or moral crusade. While traditionalist language is occasionally referenced in relation to the role of women as mothers, the movement is not primarily part of a patriarchal backlash against progressive ideals. Rather, the quest to control fertility is firmly grounded as an indirect method of increasing state power, especially military power. Mechanisms of security power saturated thinking on national defense as it was through analysis and reflection that the government determined that by acting indirectly on the object of the population, it could amplify its true goal, which was the empowerment of the state to militarily confront other aggressive foreign nations.

\footnotetext{
${ }^{34}$ Maria Sophia Quine, Population Politics in Twentieth Century Europe (1996), 63.

35 Andrés Horacio Reggiani, "Procreating France: The Politics of Demography, 1919-1945", French Historical Studies 19:3 (1996): 731.
} 
The logic of pro-natalism was explained by French Premier George Clemenceau, who argued during a debate on the ratification of the Treaty of Versailles that

the treaty does not say that France must undertake to have children, but it is the first thing which ought to have been put in. For if France turns her back on large families, one can put all the clauses one wants in a treaty, one can take all the guns out of Germany, one can do whatever one likes. France will be lost because there will be no more Frenchmen. ${ }^{36}$

Similarly, Paul Reynaud, future Minister of Justice and Commerce, declared during a debate on defense in the Chamber of Deputies that "there is one factor that dominates all: the demographic factor". ${ }^{37}$ To further entrench the point, Fernand Laurent, a deputy of the Chamber, exclaimed "denatalite (depopulation) isn't a health problem, it is a problem of national defense of the first order, perhaps the most important of all. Tomorrow it will be the problem of national defense itself". ${ }^{38}$ Thus the issue of fertility and population growth came to be synonymous with national defense. Instead of arming the people, investing in weapons research, enlarging the size of the military or other factors directly related to bolstering the armed power of the state, the government sought to act indirectly and attempted to increase the rate of population growth of the nation through birth.

This indirect approach to increasing the capacities of the state to defeat rival empires was itself approached indirectly, as per the logic of security power. The state did not decree that every citizen must produce $X$ number of offspring or attempt to regulate the sexual lives of the people such that a sufficient amount of procreative acts occurred to guarantee increased production of babies. Rather, the government sought to manipulate factors removed from the actual act of reproduction and work on issues which it believed would shape the environment for decision making such that at the level of the aggregate the fertility rate of the population as a whole would increase. Individual compliance with these manipulations was of secondary importance as the primary concern lay in shaping rates of occurrence as told through statistics.

For example, in 1920 the Chamber of Deputies passed a law which made contraceptive propaganda and any inducement to abortion illegal and punishable with up to six months in prison. Simply disseminating information on methods of birth control made one liable to criminal prosecution. ${ }^{39}$ In addition, the tax code was altered to add a surcharge of twenty five percent on the income tax payments of those who were twenty years old or more and who were unmarried. As well, childless couples who had been married for at least ten years saw an increase of ten percent on their income taxes. Legislation in 1921 gave subsidized access to public transit for large families, and in 1922 large families re-

\footnotetext{
${ }^{36}$ Michael Teitelbaum and Myron Weiner, Political Demography, Demographic Engineering (2001), 26.

${ }^{37}$ Michael Teitelbaum and Jay Winter, The Fear of Population Decline (1986), 37.

${ }^{38}$ Ibid.

${ }^{39}$ Ann Helene Gauthier, 1996. The State and the Family: A Comparative Analysis of Family Policies in Industrialized Countries (1996), 73.
} 
ceived legally sanctioned preferential treatment in rental accommodations in public housing estates. ${ }^{40}$ These measures were introduced under the mantle of the Conseil Superieur de la Natalite, which was created by the government and spearheaded by the finance minister, whose mission was to adopt all possible measures to "deter population decline, increase the birthrate, develop child care resources and to protect and honour the institution of large families". ${ }^{41}$

The widespread failure of birthrates to climb in this period was at least partly due to the fact that the operations of security power did not allow, conceptually speaking, for an appreciation of the micro foundations upon which the decision to bear children rested. All state resources went into a macro conceptualization of the population as legions of bureaucrats, administrators, academics and intellectuals laboured to create tools to best aggregate individuals into the abstracted totality of 'the population'. Once sufficiently abstracted, the state could perceive trends and rates of occurrence with ease but this incidentally stripped the operation of agency from individuals. The population became an object which was understood to be responsive to top-down engineering as the optimization of the population drove state efforts. For example, in addition to the policies described above, Mother's Day was created as a national holiday ${ }^{42}$ and military styled medals were given to mothers who produced a certain number of children to create the proper psychological climate for childbearing. ${ }^{43}$ Penalties for abortion were strengthened such that abortionists received up to ten years in prison and women convicted of having abortions could suffer two year terms of incarceration. Abortion prosecutions intensified; while in 1935 convictions numbered a mere 277, by 1940 there were 1225 criminal abortion convictions, representing a $450 \%$ increase. ${ }^{44}$

Through general disincentives to prevent pregnancy and widespread incentives, both financial and honourary, to child bearing, the state sought to act on the reified population. The population was understood to rationally respond to the mechanisms of incentive and disincentive; however, little study was done on whether these indirect manipulations would actually lead to higher birthrates or which groups of people were more susceptible to indirect encouragement. Individual wishes and micro-level rationality were deemed functionally irrelevant to policymakers, as can be seen by the fact that, for example, couples were not consulted on whether higher income tax payments would cajole them into producing more offspring. The population, as an abstraction, was understood to respond to rational mechanisms of direction, and individuals, as they actually behaved, were not the object of consideration.

Resistance to state pro-natalist campaigns proved difficult as not only was the state not consulting or interested in the opinions, wishes or motivations of the people in regard to their fertility but it actively sought to suppress countervailing discourses on the meaning

\footnotetext{
40 Michael Teitelbaum and Myron Weiner, Political Demography, Demographic Engineering, 26.

${ }^{41}$ Maria Quine, Population Politics, 74.

42 Population Politics, 77.

43 Reggiani, "Procreating France," 733.

44 Ibid., 748.
} 
of fertility. Malthusians, feminists and other actors who sought to increase the reproductive control of women and reduce the rate of child bearing were deemed traitorous as acts retarding the increase in population growth were understood to be attacks on national defense. The Ministries of War, Interior and Justice became involved in persecuting and prosecuting members of the anti-natalist movement, just as, for example, abortionists were labeled "murderers of the fatherland" and abortion was labelled a crime against the "embryo, the society, the state and the race". ${ }^{45}$ While an individual can speak out against state attempts to force higher fertility upon her, the population has no voice. National leaders can ascribe any truth to it, and with a near exclusive focus on the abstraction of the population, the state never need hear or be subject to any opposing views. Despite protestations by many individuals, the population was believed to be responsive to government control. Moreover, resistance to the state's population policies effectively became an act of treason as the discourse of national defense became intertwined with that of population growth. Strengthening the forces of national defense through indirectly attempting to shape the average fertility rate of the population rendered any opposition to pro-natalism extremely precarious as it not only had to contend with the varied interests associated with the pro natalist campaigns (and their beneficiaries) but also wrestle with the proponents of a stronger state.

It is relevant to note that at no recorded instance was any definitive numerical target set for achievement in relation to population growth. The state did not desire to increase the population by 10 million citizens or to satiate her desire for growth at 50 million inhabitants. Instead, general exhortations to increase the rate of population growth through manipulating the fertility rate were the norm. The optimization of the flow and rhythms of reproduction were the target as increasing the average number of children produced per woman became a national obsession. No state of perfection was to be achieved as there was no finality to any kind of behaviour or activity. Disciplinary mechanisms were used as a tool of security power as the rigours of the penal system, as well as the normalizing efforts of the state bureaucracy, were employed not to target the individual and shape it to a perfected state of docile obedience but instead to shape the social norms and achieve an idealized rate of occurrence.

\section{India}

Similar to the case of inter-war France, management of the reproductive powers of the population became an obsession in modern India. The power of the state was understood to lie in the wombs of the people, as narrated by the underlying discourse. Whereas France attempted to increase the fertility of its population as part of an effort to strengthen the state, India would seek to decrease the fertility rate of its people. In the post-colonial environment, a high rate of fertility was deemed a sign of backwardness and an active hindrance to development. Lowering birthrates was declared essential to any program of

${ }^{45}$ Ibid., 749. 
modernization as economic growth was believed to depend on reducing rates of population growth. Lower fertility would ease the burden on state resources and provide for a pool of savings at the individual and state level to allow for a capital base to grow, which would foster industrialization. ${ }^{46}$ Accordingly, efforts to promote family planning were undertaken as an indirect approach to increasing rates of economic growth.

As early as 1951, the Indian state declared its intent to shape the reproductive behaviours of the population to achieve national goals. The first five-year plan declared the need for "family limitation and population control" in order "to stabilize the population at a level consistent with the requirements of the national economy" ${ }^{47}$ This attitude continued through the second five-year plan as the second plan explicitly stated "the outcome of development efforts can be noticeably different if population trends are altered in the right direction. This is one of those fields in which traditional modes of thought and behavior are apt to offer considerable resistance to rational approaches" ${ }^{48}$ Here the population is explicitly identified as the object of governance and individual level understandings of the motivations for childbearing are openly scorned. The state is the 'rational' actor manipulating the abstracted whole as part of an indirect campaign to boost economic growth rates. The individual is not an object of concern or merit and its "traditional" thoughts and behaviours are to be corrected and overcome in order to achieve the results desired at the level of the aggregate.

To better entrench the power-knowledge apparatus that underpinned the operation of security power in this field, both external and internal resources were marshalled. $\mathrm{Nu}$ merous foreign experts were brought in in the form of the Ford Foundation, the Population Council, USAID, UNFPA and the World Bank to advise and assist the Indian government and to evangelize the legitimizing discourse amongst the Indian people. ${ }^{49}$ One can see the discursive power at play as external actors helped facilitate the creation of demographic institutes in Mumbai, Kolkata, Delhi and Thiruvananthapuram whose purpose was to develop new knowledges and techniques of population control. ${ }^{50}$ This was not solely an external push as internal factors were just as strong as leading political and intellectual leaders such as Nehru repeatedly urged "family limitation" in order "to promote the development of the national economy". ${ }^{51}$

\footnotetext{
${ }^{46}$ Simon Szreter, "The Idea of Demographic Transition and the Study of Fertility Change: A Critical Intellectual History" Population and Development Review 19:4 (1993); Ansley J. Coale and Edgar Malone Hoover. Population Growth and Economic Development in Low-income Countries: A Case Study of India's Prospects (1958); Dennis Hodgson, "Demography as Social Science and Policy Science" Population and Development Review 9:1 (1983)

${ }^{47}$ Christian Aspalter, "Population Policy in India", International Journal of Sociology and Social Policy 22:11/12 (2002): 50.

${ }^{48}$ Mohan Rao, From Population Control to Reproductive Health: Malthusian Arithmetic (2004): 27.

49 "Seeing Beyond the State," 645. Mohan Rao, From Population Control to Reproductive Health, 26. Phyllis Piotrow, 1973. World Population Crisis: the United States Response (1973) 14.

${ }^{50}$ From Population Control to Reproductive Health, 29.

51 "Seeing Beyond the State," 633.
} 
The plan to indirectly increase rates of economic growth through changing the fertility rate was also implemented in a relatively indirect manner, consistent with the tenets of security power. For example, the government initiated a program to provide contraceptives free of charge to those earning less than Rs (Rupees) 100 a month and half price to those earning between Rs 100 and 200. ${ }^{52}$ The number of clinics for the provision of family planning services rose from 147 at the end of the first five-year plan to 4165 by the end of the second. ${ }^{53}$ Training was intensified for all health workers and a national publicity campaign was initiated which printed over half a million posters and broadcast hundreds of radio programs in multiple languages. On average, each of India's twenty-six radio stations had a talk, discussion, dialogue or feature on family planning issues at least once every two weeks over the course of the second five-year plan. ${ }^{54}$ These roundabout methods of anti-natalist encouragement were largely ineffective in reducing the average number of children produced. Providing subsidized contraception and public pronouncements of the benefits of reduced fertility did not address the underlying rationales of reproduction. These aggregate level approaches ignored the individual level logic of procreation which, in a rural and agricultural economy such as India's in the 1950s, rested more on the production of farm labour, guarantees of old age security and the cultural value attached to fertility which children brought.

Despite the failure of the first two plans to significantly reduce fertility rates, the state remained undeterred. The quest for economic growth was deemed the ultimate imperative, and reducing the rate of population growth was understood to be a crucial part of the platform for development. Instead of focusing its resources on raising education levels, investing in factories and increasing agricultural yields, the government poured money and manpower into the anti-natalist campaign. By the 1970s Prime Minister Indira Gandhi affirmed that "there is no doubt that the rate of growth of population must be brought down, not in deference to the barrage of propaganda which is directed at us, but because of our own conviction that family planning is essential for improving our standard of living". ${ }^{55}$ Gandhi was reinforced by official policy which declared that, "if the future of the nation is to be secured... the population problem will have to be treated as a top national priority and commitment". ${ }^{56}$

Under the leadership of Indira Gandhi, action at the federal level included the freezing of the allocation of seats to parliament at the 1971 level so as not to reward districts which witnessed population increases with additional seats. Resource allocation was also based on the 1971 census data so further links between increases in population and extra resources would be severed. Additional population growth would result in the impoverishment of the people, thus, the government hoped, an incentive would be created for lower

\footnotetext{
52 Aspalter, "Population Policy in India", 52.

53 Ibid., 53.

54 "Seeing Beyond the State", 642.

55 P.K. Chaubey, 2001. Population Policy for India: Perspectives, Issues and Challenges (2001), 61.

56 Ashish Bose, 2010. India's Quest for Population Stabilisation (2010), 23.
} 
levels of government to pursue population control policies with added zeal..$^{57}$ Continued financial flows to the states became hostage to the family planning agenda as financial allocations became subject to performance criteria established by the federal level relating to the success in fertility reduction campaigns. Nationwide, the legal marriage age was raised to 18 for women and 21 for men and "population values" were introduced into the education system. Moreover, Prime Minister Gandhi supported the call for coercion; for example, at a conference of the Physicians' Association, she argued that, "we must now act decisively and bring down the birth rate. We should not hesitate to take steps which might be described as drastic. Some personal rights have to be held in abeyance for the human rights of the nation: the right to live, the right to progress". ${ }^{58}$

At the international level, many foreign observers applauded the anti-natalist drives of the Indian state. Speaking to concerns regarding the rapid and mass distribution of contraceptives such as the intra-uterine device (IUD), J. Robert Wilson, Chair of Obstetrics and Gynecology at Temple University, declared that,

we have to stop functioning like doctors, thinking about the one patient with pelvic inflammatory disease; or the one patient who might develop this, that or other complications from an intra-uterine device...it may well be that the incidence of infection is going to be pretty high in the patients who need the device most.

Wilson went further and explained that,

now obviously, if we are going to use these devices, they are occasionally going to be put in the wrong patient. Again, if we look at this from an over-all, long range view, perhaps the individual patient is expendable in the general scheme of things, particularly if the infection she acquires is sterilizing but not lethal.

Similarly, Alan Guttmacher, Chief of Obstetrics at Mount Sinai Hospital in New York and the President of Planned Parenthood, advocated that only nurses and midwives be given the task of implanting IUDs in the third world due to concerns about time and cost efficiency. When questioned by other doctors who advocated that only a trained physician should insert the IUD after a thorough examination due to the risks of pain, bleeding and spontaneous expulsion, Guttmacher objected and stated that obtaining a patient's medical history, "would make a more time consuming job out of intra-uterine contraception...We dare not lose sight of our goal - to apply this method to large populations". ${ }^{59}$

The population in its abstracted form reigned as the object of governance, and individuals, when they were considered, were seen as relatively inconsequential. Indeed, some went as far as to argue that individual lives were near expendable as the quest was not to perfect individual behavior or to produce productive citizens (as is the case in disciplinary power) but to shape the population as a reified entity. The collection of totalizing data on

\footnotetext{
${ }^{57}$ From Population Control to Reproductive Health, 46.

58 Ibid., 47.

${ }^{59}$ Matthew Connelly, 2008. Fatal Misconceptions (2008), 202.
} 
individuals, a major plank of disciplinary power, was exchanged for the amassing of knowledge of the population as told through statistics. The Prime Minister of India herself stated that the individual was subservient to the nation and that the goal of shaping aggregated rates of behavior overrode any individual desires. The right of the nation, an abstract entity, to progress was the determining factor and individual desires were subordinated to the reified whole. Moreover, medical professionals the world over abandoned their focus on individual care and shifted to a Foucauldian security perspective as the individual became obsolete in relation to the population.

Governance by and through rates of occurrence and averages became the norm, and the indirect manipulation of these statistical constructs dominated as the Indian government sought to achieve high rates of economic growth. Organized opposition to population control was meagre as the social forces resisting government control of procreation had not only to contend with the issue of 'the state in the bedroom' but with the underlying discourse on development. Resistance grounded in cultural values, individual freedom, female choice or any other issue relating to the reproductive act itself merely addressed one level of the power nexus. The indirect manipulative forces worked at multiple levels as the primary concern was not individual reproduction itself nor even control over the fertility rate per se but that of regulating the rate of economic growth. The depth of the relationship between security power and power-knowledge made it such that resistance required a similar depth of nexuses which proved exceedingly difficult to attain at the local level. While this discourse was challenged in a somewhat successful manner by an international coalition of activists at the 1994 Cairo Conference on Population and Development, which helped transform the global discourse towards a more individual and female centric model of choice, ${ }^{60}$ in the year 2000 the National Commission on Population stated as its objective "to bring the TFR (total fertility rate) to replacement levels by 2010 through vigorous implementation of inter-sectoral operational strategies. The longterm objective is to achieve a stable population by 2045, at a level consistent with the requirements of sustainable economic growth, social development, and environmental protection," an objective permeated with the language and practices of security power. ${ }^{61}$

\section{Conclusion}

Security power represents the "third modulation" of power and an evolution from the powers of sovereign and discipline. While sovereign power focused on the spectacle of violence directed at an individual (as well as the observing crowd) and disciplinary power sought to produce docile and capable individuals through a totalizing mechanism of surveillance and control, security power represents a marked rupture from the individualistic focus of previous forms. Security reorients the lens of the state towards the population as a whole to the relative neglect of the individual. This is not to say that the state does

${ }^{60}$ C. A. McIntosh and J. L. Finkle. "The Cairo Conference on Population and Development: A New Paradigm?" Population and Development Review 21:2 (1995): 223

${ }^{61}$ National Commission on Population, Ministry of Health and Family Welfare, Government of India, 2000. 
not seek to operate on individuals but rather that the primary objective is no longer the individual. The eye of the state rests on the population as an abstraction, often represented in the image of the average individual. An expanded power-knowledge apparatus creates a novel nexus of actors who work to aggregate and collectivize knowledge of the population as a whole. The individual ceases to operate as the site of concern as the "species" effectively takes centre stage. ${ }^{62}$

This becomes apparent in the history of population control as analyzed in the cases of inter-war France and post-colonial India. The population as a whole became the object of governance and the individual itself was deemed rather insignificant by a wide range of political actors. Individuals mattered in as much as they were data points contributing to the statistical construct of an abstracted entity. Manipulations at the level of the abstract focused on averages, rates and norms as the continual process of optimization became the stated desire, as opposed to the ideal of a perfect end-state found in disciplinary power. Indira Gandhi and George Clemenceau shared a common language relating to the necessity of harnessing the fertility of the nation to achieve national ends. Whether it be militarily defeating rivals or achieving high rates of economic growth, the individual and its reproductive desires were functionally irrelevant as the population was the only true site of concern in the pursuit of state objectives.

Moreover, state behaviour sought to operate indirectly as manipulating factors removed from the objective itself were understood to achieve better results. While disciplinary power decreed direct compliance, security power sought to shape the environment for decision making as a cost-effective strategy such that, at aggregate levels, rates of occurrence would shift in line with state aims. France sought to increase the fertility rate so as to indirectly boost the military and economic potentials of the state for future, imagined conflicts with foreign rivals. India desired to decrease the average number of children the average woman would have as part of an indirect attempt to increase the rate of economic growth to achieve 'development'. These indirect manipulations of average indicators to achieve abstract realities of power and modernity are hallmark features of the discourse and practice of security power.

In these cases, security power worked in tandem with a biopolitical understanding as the very essence of life, as seen in the practices and moment of natality, and were where government leaders sought to exercise control. The creation of life itself, the nucleus of our biological existence, was harnessed to further state objectives. While not every exercise of security power involves a biopolitical component, a growing portion of government behaviours do integrate security with biopower as part of a comprehensive attempt to maximize the power of the state. Nowhere is this more true than in the modern preoccupation with population politics as the vast majority of states, both developed and developing, are using the tools of security power to harness the powers inherent in the biooperations of individuals to maximize state potential.

An understanding of the complex nature in which security power operates is critical to the possibilities of resistance and acknowledging the potential for policy failure. Situating

62 Security, Territory, Population, 75. 
the object at the level of the population, indirect manipulation and reliance on an elaborate network of power-knowledge all serve to frustrate individual attempts to resist government action. Barriers are raised at the conceptual and practical levels for successful individual action. For example, the individual must contend with deeply entrenched disregard for individual input at the governmental level as the individual is fundamentally decentered as an object. Furthermore, multiple sites of entrenched interest must be overcome as both directly and indirectly affected actors become involved in maintaining government control. In addition, robust discursive frames must be challenged if one is to overcome the operation of security power as the operation of power-knowledge is deeply intertwined with security. Examples throughout the article highlight these challenges as individual resistance in France, India and Nigeria is frustrated by powerful operations of governmentality.

However, the methods which make resistance difficult may themselves sow the seeds of ineffective policy. Government leaders often make themselves systematically ignorant of the micro-foundations of individual realities and so may overlook the actual mechanisms by which compliance with policy is achieved. For example, in India the government routinely ignored, or remained relatively ignorant of, the actual wishes of the citizenry for ideal family size. Those who regarded children as a source of wealth and familial security are unlikely to limit their fertility in response to a government subsidy for sterilization. By targeting 'the population' as an aggregated entity rather than micro targeting sections of the people based on individualized data, the state makes itself more prone to policy failure. Consequently, through an understanding of the workings of security power as articulated by Foucault, and through the concretization of its operation in the cases of India and France, we can broaden our understanding of the ways in which power has evolved and provide for improved analysis as to the obstacles which must be overcome to contend with this new modulation of power.

\section{References}

Aspalter, Christian. 2002. "Population Policy in India", International Journal of Sociology and Social Policy 22:11/12 (2002), 48-71 https://doi.org/10.1108/01443330210790193

Barret, Deborah. and Tsui, Amy Ong. "Policy as Symbolic Statement: International Response to National Natalist Policies" Social Forces 78:1 (1999), 213-234 https://doi.org/10.1093/sf/78.1.213

Bose, Ashish, India's Quest for Population Stabilisation New Delhi: National Book Trust, 2010.

Caldwell, John and Caldwell, Pat, Limiting Population Growth and the Ford Foundation Contribution London: Frances Pinter, 1986.

Chaubey, P.K., Population Policy for India: Perspectives, Issues and Challenges New Delhi: Kanishka Publishers, 1986.

Coale, Ansley J., and Hoover. Edgar Malone, Population Growth and Economic Development in Low-income Countries: A Case Study of India's Prospects Princeton: Princeton University Press, 1958. 
Connelly, Matthew, "Seeing Beyond the State: The Population Control Movement and the Problem of Sovereignty", Past and Present 193 (2006), 197-233 https://doi.org/10.1093/pastj/gt1016

Connelly, Matthew, Fatal Misconceptions London: Harvard University Press, 2008.

Demeny, Paul. 2003. "Population Policy: A Concise Summary" Population Council, Policy Research Division, Working Paper No. 173

Foucault, Michel, Discipline and Punish: The Birth of the Prison. New York: Vintage Books, [1975] 1995.

Foucault, Michel, Society Must be Defended: Lectures at the College de France 1975-76 New York: Picador, 1997.

Foucault, Michel. Security, Territory, Population: Lectures at the College de France 1977-78 New York: Palgrave Macmillan, [2004] 2009.

Gauthier, Ann Helene, The State and the Family: A Comparative Analysis of Family Policies in Industrialized Countries Oxford: Clarendon Press, 1996.

Greenhalgh, Susan, "The Chinese Biopolitical: Facing the Twenty-First Century”, New Genetics and Society 28:3 (2009), 205-222 https://doi.org/10.1080/14636770903151992

Hodgson, Dennis, "Demography as Social Science and Policy Science", Population and Development Review 9:1 (1983), 1-34 https://doi.org/10.2307/1972893

Hodgson, Dennis, "Demography: Twentieth Century History", International Encyclopedia of the Social and Behavioural Sciences New York: Elsevier, 2001. https://doi.org/10.1016/B0-08043076-7/02082-9

Johnson, Stanley, World Population and the United Nations: Challenge and Response New York: Cambridge University Press, 1987.

Keil, Thomas and Andreescu, Viviana, "Fertility Policy in Ceausescu's Romania”, Journal of Family History 24:4 (1999), 478-492 https://doi.org/10.1177/036319909902400405

Kligman, Gail, "The Politics of Reproduction in Ceausescu's Romania: A Case Study in Political Culture" East European Politics and Societies $6 \quad$ (1992) 364 https://doi.org/10.1177/0888325492006003010

Kligman, Gail, The Politics of Duplicity Los Angeles: University of California Press, 1998.

MacKinnon, Mark. China Undertakes First national Census in 10 Years. The Globe and Mail, 2010, 31 Oct.

McIntosh, C. A. and Finkle, J. L., “The Cairo Conference on Population and Development: A New Paradigm?" Population and Development Review 21:2 (1995), 223-260 https://doi.org/10.2307/2137493

National Commission on Population, Ministry of Health and Family Welfare, Government of India, 2000. Accessed March 30, 2016 http://populationcommission.nic.in/content/684_1_NationalPopulationPolicy2000.aspx

Piotrow, Phyllis. World Population Crisis: the United States Response New York: Praeger Publishers, 1973.

Quine, Maria Sophia. Population Politics in Twentieth Century Europe London: Routledge, 1996. https://doi.org/10.4324/9780203410592 
Rao, Mohan. From Population Control to Reproductive Health: Malthusian Arithmetic New Delhi: Sage Publications, 2004.

Reggiani, Andrés Horacio, "Procreating France: The Politics of Demography, 1919-1945", French Historical Studies 19:3 (1996), 725-754 https://doi.org/10.2307/286642

Renne, Elisha, "Perceptions of Population Policy, Development and Family Planning Programs in Northern Nigeria", Studies in Family Planning. 27:3 (1996), 127-136 https://doi.org/10.2307/2137918

Scott, James, Seeing Like A State. New Haven: Yale University Press, 1999.

Szreter, Simon, "The Idea of Demographic Transition and the Study of Fertility Change: A Critical Intellectual History", Population and Development Review 19:4 (1993), 659-701 https://doi.org/10.2307/2938410

Teitelbaum, Michael and Weiner, Myron, Political Demography, Demographic Engineering New York: Berghahn Book, 2001.

Teitelbaum, Michael and Winter, Jay, The Fear of Population Decline London: Academic Press, 1986.

United Nations Department of Economic and Social Affairs, Population Division, World Population Policies 2013 Report New York: United Nations, 2013.

World Bank, The McNamara Years at the World Bank Baltimore: John Hopkins University Press, 1981.

Author info

Richard Togman, PhD

Lakehead University

Canada

togman@alumni.ubc.ca 